\title{
Legal and Practical Issues Related to Telework: The Example of Estonian Law
}

\author{
Gaabriel Tavits \\ University of Tartu, School of Law \\ Professor of Social Law \\ E-mail:gaabriel.tavits@ut.ee \\ Aleksei Kelli \\ University of Tartu, School of Law \\ Professor of Intellectual Property Law \\ E-mail:aleksei.kelli@ut.ee
}

Telework as a new form of employment has become particularly relevant with the advent of the COVID-19 restrictions. So far, telework has been used occasionally, and only a few employers and employees have resorted to this mode of work. Due to the COVID-19 situation, telework has become a reality, and at times it is the only possibility to work. Although telework is widely used, the legal regulation might not be apparent. The article explores the specific aspects of legal regulation regarding telework in Estonia.

Keywords: telework, employment conditions, working time, employee privacy.

\section{Contents}

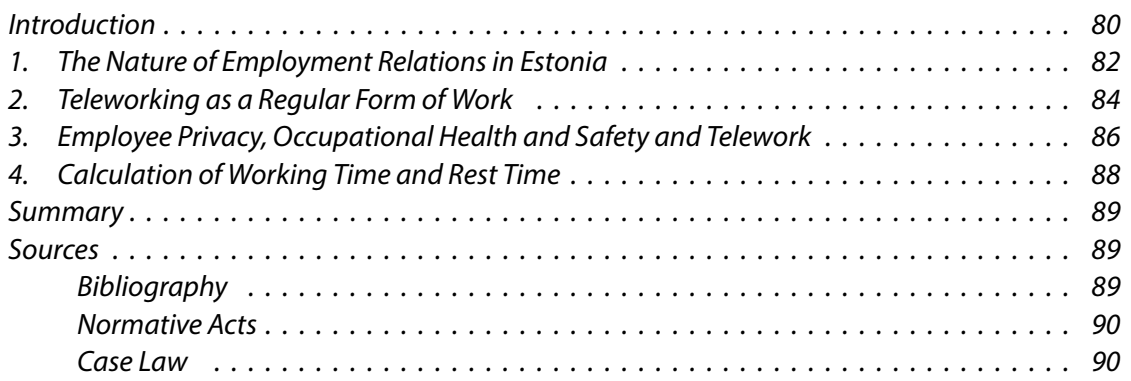

\section{Introduction}

Digitalisation and the sharing economy are considered essential topics at the EU level. Thus, the EU has endorsed the plan for digitalisation. The European Union also endorsed the principles of the sharing economy. Estonia pays attention to digital solutions aimed at the communication of the state with its citizens. The main goal is to offer the population faster ways to communicate with the state authorities and as much as possible to ensure paperless administration. These developments enable various tasks that no longer require a traditional job with a physical presence or a conventional employer. At the same time, it must be borne in mind that not all 
types of work can be digitized at present. Therefore, also the significance of telework has increased. ${ }^{1}$

Teleworking entails many technical and legal issues. From a technical point of view, internet access is a condition sine qua non. The is acknowledged by the Estonian government as well. Estonia has adopted an information society development plan. ${ }^{2}$ One of the goals set out in this document is to ensure the availability of high-speed internet and digital skills.

Regarding the information society plan, it is pointed out that almost 300000 people in Estonia have not yet used the internet. Although the Estonian state takes numerous different steps to encourage people to learn to use various digital communication tools, attention has been paid primarily to those population groups in a somewhat weaker position in the Estonian labour market. Less attention has been given to the potential of the internet for the creation of high-quality jobs.

Teleworking also raises human rights issues. The key questions include how and whether an employer can compel an employee to work from home and whether such an obligation is not contrary to Article 8 of the European Convention for the Protection of Human Rights and Fundamental Freedoms (hereinafter - Human Rights Convention). ${ }^{3}$

A range of data protection issues accompanies this mode of work. In addition to the customary questions - when and whether the employer can read the e-mails sent by the employee at all, data protection concerns related to the processing of different data and the transmission of such data to different employees and the co-operation partner are vital. Who is authorised to process the data, and who is the controller? ${ }^{4}$

The authors address the changes in employment relations and their legal regulations that have taken place in Estonia in connection with the introduction of new digital opportunities. In the first place, the legal regulation of telework and the problems arising in connection with telework are analysed. Estonian labour legislation does not define the concept of telework. The Employment Contracts Act (hereinafter - ECA) ${ }^{5}$ merely states that an employee and an employer may agree that an employee performs duties outside his usual place of work. The duration of telework and the rights and obligations of the parties to the employment contract are not specified.

The current legal regulation has not responded to changes in employment relationships and working methods. It remains a private agreement between both the employer and the employee. The state does not directly prevent the conclusion of separate agreements, but such agreements must not worsen the employee's situation in comparison with the requirements established by law.

1 Telework in the EU before and after the COVID-19: where we were, where we head to. Available: https://ec.europa.eu/jrc/sites/jrcsh/files/jrc120945_policy_brief_-_covid_and_telework_final.pdf [last viewed 28.02.2021].

2 Eesti infoühiskonna arengukava kuni 2020 [Development plan for Estonian information society until 2020]. Available: https://www.mkm.ee/sites/default/files/eesti_infouhiskonna_arengukava.pdf [last viewed 27.02.2021].

3 European Human Rights Convention. Available: https://www.echr.coe.int/Documents/Convention ENG.pdf [last viewed 27.02.2021].

4 This question is outside of the scope of the present article.

5 Employment Contracts Act. Available: https://www.riigiteataja.ee/en/eli/529122020003/consolide [last viewed 27.02.2021]. 


\section{The Nature of Employment Relations in Estonia}

In Estonia, individual employment relationships are regulated by the Employment Contracts Act. This law is based on the principle of flexicurity used in the European Union. According to the ECA, the employment contract does not necessarily have to be concluded in writing. The requirements for terminating the employment contract have been simplified. The number of significantly different formal requirements have been reduced. Although the ECA leaves sufficient space for the parties to the employment contract to enter into individual agreements, the ECA has been criticised for not providing sufficient flexibility in the situation where working conditions have changed. This also concerns teleworking. The issues related to working time are insufficiently regulated. Concerning working time, the parties to an employment contract do not have enough freedom to decide how many hours an employee still has to work. ${ }^{6}$

According to Section 28 of the Constitution, ${ }^{7}$ everyone has the right to choose their field of activity and workplace freely. Section 19 of the Constitution states that everyone has the right to self-determination, also complies with this provision. The principle of freedom of contract is likewise derived from that provision. Consequently, everyone has the right to decide with whom to conclude an employment contract. This principle also guarantees the possibility to determine whether and with whom to terminate a contract. The employee and the employer can decide with whom and under what conditions the employment contract is concluded. The conditions of employment are under state control. Under this principle, the state can establish the necessary and required working conditions and, in addition, exercise control over the fulfilment of these conditions.

The ECA also regulates teleworking. The provisions of the ECA on the regulation of telework are general and leave the employee and the employer the opportunity to reach agreements to the extent necessary and appropriate for them. The Confederation of Estonian Trade Unions and the Confederation of Estonian Employers have also agreed on the principles of applying telework. ${ }^{8}$ Although these principles are not mandatory (they are not generally a binding collective agreement), they constitute the principles that both employers and employees are expected to follow.

When regulating employment relations, Estonia must consider that public service employment is also relevant in addition to regular employment based on an employment contract. According to the Civil Service $\mathrm{Act}^{9}$ in force in Estonia, employees in the public service are divided into two categories: officials and employees on the basis of an employment contract. Officials are appointed by administrative act and are generally not subject to labour law. According to the Civil Service Act Section 67 (3), the possibility of teleworking is also provided. However, the Civil Service Act does not specify which conditions should be applied in

6 Töötamisega seotud regulatsioone tuleb muuta paindlikumaks [Regulations concerning employment must be more flexible]. Available: https://www.koda.ee/et/uudised/tootamisega-seotud-regulatsioonetuleb-muuta-paindlikumaks [last viewed 27.02.2021].

7 The Constitution of the Republic of Estonia. Available: https:/www.riigiteataja.ee/en/ eli/530122020003/consolide [last viewed 26.02.2021].

8 Kaugtöö kokkulepe [Agreement on telework]. 25.05.2017. Available: https://www.eakl.ee/ kokkulepped/kaugtoo-kokkulepe [last viewed 26.02.2021].

9 Civil Service Act. Available: https://www.riigiteataja.ee/en/eli/525032019003/consolide [last viewed 26.02.2021]. 
telework. The collective agreement between the two confederations referred to above is also applicable by analogy in the public service.

The provisions of the ECA on telework are general and leave the employee and the employer considerable freedom in determining their relations. Observing and ensuring compliance with occupational health and safety requirements is imperative concerning teleworking. This is one of the critical issues, the specific solution to which is being sought by many countries, not only in Estonia. Although telework in many countries is regulated by legislation at different levels, occupational health and safety requirements have mostly remained unchanged. The Estonian Occupational Health and Safety $\mathrm{Act}^{10}$ does not alter the prescribed liability for occupational safety between an employee and an employer. The employer is fully responsible for compliance with occupational health and safety requirements in all work situations, including teleworking. This principle has not been changed, nor has it been altered in the context of COVID-19. When other working conditions in telework are a matter of agreement between the parties, then ensuring occupational health and safety requirements is ultimately the employer's responsibility. The employer is responsible for non-compliance with these requirements. One way to change this is to transfer responsibility for health and safety at work onto the teleworker. This could be possible when the employer has informed the employee about the risks of teleworking. If such information is provided, the employer is released from liability in the event of possible damage to employee's health.

One of the essential issues in implementing teleworking is the employee's right to his or her private life. The Estonian Constitution provides that everyone has the right to the protection of his or her privacy. ${ }^{11}$ The right can only be restricted on a legal basis if there are good reasons for that. A similar right is also enshrined in Article 8 of the Human Rights Convention. Besides, under Article 8, it is possible to restrict this right by law if it is necessary and essential in a democratic state governed by the rule of law. When implementing teleworking (especially working from home), the question arises here, whether the employer can unilaterally oblige the employee to work from home (e.g., in the case of COVID-19). To answer the above question, it is necessary to analyse issues that an employer may unilaterally require to work from home. Such a unilateral requirement by the employer can only be relevant if provided for by law or necessary for protecting the health and safety of other workers. Under the Human Rights Convention, the requirement of legality obliges the legislator to pass a specific law. Yet, it is also sufficient if, for example, the national government is authorized to enact such legislation. ${ }^{12}$

The application of teleworking has become a new norm since the advent of COVID-19. Countries are left with choices about how and in what forms to do it. Occupational health and safety guidelines were adopted in Estonia even before the wave of the COVID-19 virus, and they should be followed in the performance of

10 Occupational Health and Safety Act. Available: https://www.riigiteataja.ee/en/eli/522022021001/ consolide [last viewed 26.02.2021].

11 Section 33 of the Estonian Constitution.

12 Guide on Article 8 of the European Convention on Human Rights. Available: https://www.echr.coe. int/documents/guide_art_8_eng.pdf [last viewed 26.02.2021]. 
telework. ${ }^{13}$ These guidelines are not mandatory but set out clear requirements that both the employer and the employee must observe to prevent the employee's health from deteriorating. Still, some of the employers have adopted the internal rules on telework.

\section{Teleworking as a Regular Form of Work}

Typically, when talking about new ways of working, the possibilities and ways of remote working are also relevant. There is no single definition for telework. It is characterised by the fact that the employee does not have to be physically present in the regular place of work, but instead, the work is done remotely. ${ }^{14}$ For such work to be possible, technical means of work are necessary. Typically, it means a situation where the employee does not have to leave home and can perform his duties at home using various information technology tools and options. From this point of view, there are also obligatory tools that allow performing tasks in the prescribed volume and under the prescribed conditions (computer with the necessary capacity, webcam, microphones, internet connection with sufficient speed to download and upload files).

Teleworking can take different forms to perform the tasks. On the one hand, there can be a case where the employee is not at work. An employee does not have a workplace with his employer, and the entire work is carried out from home or another place. On the other hand, teleworking can be a case where an employee works remotely a few days a week, for example, at home, whereas the rest of the time, an employee is present in his regular place of work. Moreover, teleworking, which involves creating office space and the presence of employees representing several employers, is not ruled out. The office space is equipped with the necessary resources, enabling employees to perform their duties on site. An employee may work at home or in other places. The employment contract can also stipulate that the employee is at the workplace provided by the employer two days a week. The rest of the time, the employee works in a place that suits him. The workplace, in case of the telework, does not necessarily have to be at employees' home.

In terms of employment law, telework differs from other ways of work because the employee may not be physically located at the employer's workplace, and the employer does not have the opportunity to control whether and how the employee performs his duties. Nevertheless, since work tasks are performed using modern information and communication means, the employer can still control the performance of work tasks if the necessary control mechanisms have been established.

Owing to the COVID-19 restrictions, teleworking has become a standard work option. Indeed, not all activities permit home-based work (e.g., construction or other spheres). In some situations, when the worker is not allowed to go to work, taking into account all potential restrictions on movement, work from home is the only way to continue working. Such changes in the situation have brought along

13 Kaugtöötaja töötervishoid ja - ohutus [Teleworker - occupational health and safety]. Available: https://www.tooelu.ee/UserFiles/Sisulehtede-failid/Teemad/Paindlikud\%20t\% C3\% B6\% C3\%B6v\%C3\%B5imalused/Kaugtootaja\%20tootervishoiu\%20ja\%20-ohutuse\%20juhis.pdf [last viewed 26.02.2021].

14 Haddon, L., Brynin, M. The Character of Telework and the Characteristics of Teleworkers. 2005. Available: http://eprints.lse.ac.uk/67001/1/Haddon_character_of_telework.pdf[last viewed 26.02.2021]. 
new issues, which so far in teleworking were either not regulated at all or lacked regulation of a sufficient extent and scope.

According to the ECA, if the tasks are performed remotely, the performance of the specified work must be agreed in the employment contract. The ECA does not specify what the working conditions are in the case of telework, nor does it stipulate what the rights and obligations are and what means of employment must be guaranteed by the employer to the employee. These obligations are left to the agreement of the parties.

As mentioned above, certain principles for organizing telework were agreed upon between the Confederation of Estonian Trade Unions and the Estonian Employers' Confederation for 2017. This agreement is of an indicative nature. Although the aforementioned agreement referred to teleworking on a voluntary basis and on the basis of an agreement between the parties, under the conditions that changed due to COVID-19, the transition to teleworking was compulsory rather than agreement-based. Especially in the spring of 2020, when the first wave of the COVID-19 and the restrictions stepped in unexpectedly. Employers had no choice but to arrange for employees to work remotely where it was feasible, and the nature of the work allowed to do so. There was relatively little time left to agree on which conditions would be applicable to telework.

Estonian labour legislation addresses the question of agreement of the parties as to whether and under what conditions organizing of telework is realizable. The law does not specify the rights and obligations of employees and employers.

A more significant aspect of teleworking is ensuring compliance with the working and rest time prescribed by law and agreeing expressly on the time from which the employee must be available to the employer to perform work-related tasks. There is also a need to agree on how and to what extent the costs related to the resources required for carrying out the work should be covered.

In the case of teleworking, compliance with occupational health and safety requirements remains of major importance. The current legal regulation of occupational health and safety is aimed at achieving that the employer is generally responsible for compliance with the requirements related to occupational health and safety. Although the employee is also obliged to comply with occupational health and safety requirements, the employer is ultimately responsible for meeting these requirements.

The Estonian Occupational Health and Safety Act stipulates the same principle - the employer is responsible for compliance with occupational health and safety requirements. The employer must instruct the employee and explain to them the risks associated with teleworking. Still, the employer will not be excused from liability should the employee's health deteriorate during teleworking. In this respect, the improvement of the relevant legal regulation in Estonia is impending, as the division of responsibility for compliance with occupational health and safety requirements in telework should be imperative.

In Estonia, the Chamber of Commerce and Industry proposed that the employee be responsible for safe working conditions if the employer has informed the employee about the risks of teleworking. It should therefore imply a division of responsibilities between the employee and the employer. ${ }^{15}$

15 Töötamisega seotud regulatsioone tuleb muuta paindlikumaks [Regulations concerning employment must be more flexible]. 


\section{Employee Privacy, Occupational Health and Safety and Telework}

Teleworking does not necessarily entail the violation of the employee's privacy. The employee consents to telework and therefore accepts the necessary restrictions. It is compatible with the General Data Protection Regulation (hereinafter - GDPR). ${ }^{16}$ Article 6 (1) of the GDPR allows the processing of the employee's personal data ${ }^{17}$ for the performance of a contract (clause b) and the legitimate interests (clause $f$ ).

Privacy issues may ensue when telework is required unexpectedly, and neither the employee nor the employer can implement different measures. Considering COVID-19 outbreak in spring 2020, one can ask whether and to what extent the employer had an obligation and the right to unilaterally oblige the employee to transfer to the telework?

Article 8 of the Human Rights Convention, which states that everyone has the right to privacy, has a key role here. This situation also concerns a person's right to the dwelling. According to Article 8 of the Human Rights Convention, the right to interfering with privacy is not unlimited. Under Article 8 , it is permissible to interfere with a person's privacy if it is necessary in a democratic society, and such a possibility is also provided by law. It does not matter whether it is a law adopted by the parliament. According to the European Court of Human Rights case law, the legal basis can be constituted by any legal act, whether enacted by law or set forth in accordance with the law.

Therefore, an employer's order to work at an employee's home office needs a legal basis. What the legal basis must be is not specified by the Human Rights Convention. An emergency situation was declared in Estonia on 12 March 2020. Based on the emergency situation, the Government of the Republic acquired the competence to establish various restrictions, including restrictions related to the movement of people. The establishment of such a state of emergency gives the employer the right to oblige an employee to work remotely if this is necessary in a democratic society and also protects the rights and freedoms of others.

There is one more aspect to be noted here. When Estonia declared a state of emergency, the Estonian government sent a notice to the Council of Europe to suspend the guarantee of the rights and freedoms provided for in the ECHR during the emergency. ${ }^{18}$ Such an opportunity is provided for by Article 15 of the Human Rights Convention. Does such an exercise of the right automatically mean that the rights and freedoms provided for in the ECHR may be restricted? Even if it were held that the state had the possibility to impose restrictions on the suspension of the rights provided for in Article 8, this did not nullify the restriction of the right to privacy provided for in Sections 33 and 43 of the

16 Regulation (EU) 2016/679 of the European Parliament and of the Council of 27 April 2016 on the protection of natural persons with regard to the processing of personal data and on the free movement of such data, and repealing Directive 95/46/EC (General Data Protection Regulation). Available: https://eur-lex.europa.eu/eli/reg/2016/679/oj [last viewed 13.09.2021].

17 Article 4 (1) of the GDPR defines personal data as information relating to an identified or identifiable natural person.

18 Reinsalu: hädaolukorras võidakse piirata inimõiguste konventsioonis tagatud õigusi [Reinsalu: In case of emergency, human rights can be restricted]. Available: https:/www.delfi.ee/news/ paevauudised/eesti/reinsalu-hadaolukorras-voidakse-piirata-inimoiguste-konventsioonis-tagatudoigusi?id=89384059 [last viewed 26.02.2021]; Lõhmus, U. Lisandusi inimõiguste konventsiooniga võetud kohustuste peatamisele [In addition to suspended obligations arising from the Human Rights Convention]. Available: https://www.err.ee/1070879/uno-lohmus-lisandusi-inimoiguste-konventsioonigavoetud-kohustuste-peatamisele [last viewed 26.02.2021]. 
Estonian Constitution and the legal consequences thereof. ${ }^{19}$ According to the Estonian Constitution, it is also possible to place restrictions on a person's private life if necessary to protect the rights of other persons. Restrictions on movement are imposed and needed to limit the spread of the virus. The measures taken to do so are necessary to protect the rights and freedoms of others. Therefore, it is in accordance with the Estonian Constitution that an employer orders an employee to work remotely if this is necessary to ensure the rights and freedoms of other persons. For the employer to issue such an order, the state must issue a general order imposing restrictions on movement. Based on general restrictions, the employer can also unilaterally reorganize work according to the changed overall situation.

However, one problem remains when there are no overall restrictions in the country, but the employer wants to impose such restrictions in his company to prevent, for example, the spread of the virus or other infectious diseases (to prevent a local outbreak). If the employer wishes to impose such restrictions itself, it can do so only if legislation provides a basis for such action.

Under the Occupational Health and Safety Act, the employer must ensure a safe working environment and healthy working conditions. These occupational health conditions must be ensured in such a way that the health, rights and freedoms of other workers are not adversely affected. The Occupational Health and Safety Act provides an opportunity to reorganize work. Still, it does not confer upon the employer the unilateral decision-making right to direct an employee to telework. The employer can send the employee to work at home on a condition that it provides the corresponding work equipment and a safe work environment (e.g., a suitable desk, office chair, etc.) needed for work.

If the employer gives an order to stay at home, this order is also justified, but the employee refuses to do so. It must be considered that the employee may commit a breach of work obligations. For example, according to the Estonian Employment Contracts Act, the law stipulates the employee's obligation to refrain from violating the rights of other employees, and the employee also has an obligation to do everything in his power to avoid harming the health of other employees. When an employee comes to his regular workplace despite the employer's instructions, thus he by his presence endangers the health of other employees. Such behaviour in the employment relationship entails the responsibility of the employer for ensuring safe working conditions. Still, at the same time, it may also lead to the employee's individual responsibility (e.g., due to breach of non-contractual obligations). Because of the above, the employer's decision to assign the employee to working remotely must be made in accordance with the law and the actual situation at the workplace. If the employee disregards the employer's order to perform telework even if the situation at the workplace requires this measure, the employee assumes responsibility for such behaviour. In addition to being liable to the employer, it is conceivable that an employee is personally liable to co-workers if his behaviour may lead to health problems of other employees.

19 Lõhmus, U. Lisandusi inimõiguste konventsiooniga võetud kohustuste peatamisele [In addition to suspended obligations arising from the Human Rights Convention]. 


\section{Calculation of Working Time and Rest Time}

The issue of working and rest time is one of the critical topics in employment. The more flexible the working conditions, the more crucial the relationship between working time and rest time. The proper ratio of working and rest time ensures the employee's efficiency. Compliance with the working and rest time requirements ensures that the employee is provided with the necessary occupational health and safety conditions. The ECA complies with the Working and Rest Time Directive requirements established by the European Union, ${ }^{20}$ related to the restrictions on maximum working hours and compliance with the requirements for minimum rest periods. Under Section 28 (2) 4) of the ECA, the employer is obliged to ensure the control of working and rest time and ensure that the necessary records are kept regarding the use of working and rest time. In its judgment, the ECJ has drawn attention to how the employer must keep working time records. ${ }^{21}$ The European Working Time Directive does not explicitly provide a single measure on how the calculation of working and rest time should be ensured, leaving the choice to the Member States. The Employment Contracts Act does not describe how the employer must keep these records and whether and in what cases the representative of employees has access to these records.

The calculation of working time makes it possible to determine whether and to what extent employees have had to work overtime and whether the necessary rest requirements have been complied with. Although the Employment Contracts Act does not oblige the employer to introduce a specific accounting system or prescribe how the said accounting system for working and rest time should be introduced regarding employees, it is up to the employer to comply with this obligation.

The spread of digitalization means that the employee does not have to be always virtually reachable by the employer. The only aspect that matters is that his job should be fulfilled and, if necessary, the employee must be available to the employer for professional communication. Consequently, the employee may be independent in planning his working and rest time. Concerning rest time, the ECA allows the employer to divide the rest period into parts based on an agreement prescribed in the employment contract. According to Section 51 of the ECA, the rest period between working days must be at least 11 hours. This rest period can be divided into parts by an agreement in the employment contract. There are also restrictions on splitting rest time. The duration of one part of the rest period shall be at least six consecutive hours, and the work shall not endanger the health and safety of the worker. If such a rest period is agreed upon in the employment contract, the employer must comply with this requirement. It is not only compliance with the requirements prescribed by the ECA. Above all, the restrictions important from the point of view of occupational health and safety must be respected. This provision becomes significant in teleworking when uninterrupted rest may not be possible in all cases. Here, the employer's obligation to ensure that the employee complies with the requirements for the regulation of rest time is principal. From the legal regulation, the regulation of working and rest time and occupational health and

20 Directive 2003/88/EC of the European Parliament and Council of 4 November 2003 concerning certain aspects of the organisation of working time. Available: https://eur-lex.europa.eu/legal-content/ $\mathrm{EN} / \mathrm{TXT} / \mathrm{PDF} /$ ?uri=CELEX:32003L0088\&from=ET [last viewed 26.02.2021].

21 Judgment of the Court (Grand Chamber) of 14 May 2019. Federación de Servicios de Comisiones Obreras (CCOO) v. Deutsche Bank SAE. Case No. C-55/18. Available: https://eur-lex.europa.eu/legalcontent/EN/TXT/?uri=CELEX\%3A62018CJ0055 [last viewed 26.02.2021]. 
safety requirements remain the employer's responsibility. Here, a particular change in trend must be considered.

Concerning working and rest time, the employee and the employer must agree on the time intervals during which the employee must be available. An employee cannot be required to be available 24 hours a day. The regulation of working and rest time can be provided by law, but the possibility becomes sufficient if the employee and the employer reach a corresponding agreement.

\section{Summary}

The changed situation incurs new challenges to the regulation of labour relations. While in the near past we considered teleworking as one of the optional alternatives to working and earning income, today it may be said that in some cases, telework is the only way for people with different mobility restrictions to work and make a living.

Estonian labour legislation does not formally regulate telework and the conditions for its application. There is only one provision in ECA, according to which there is a possibility to apply telework by mutual agreement of the parties. The parties determine the conditions of the telework agreement to the employment contract.

Compliance with the rules of working and rest time and occupational health and safety requirements have remained the employer's responsibility, even if the employee works remotely. Although the employer must ensure occupational health and safety requirements, it is worth considering the division of responsibilities between the employer and the employee in telework. This is especially the case when the employer has informed the employee about the risks of teleworking.

A dominant legal issue is a possibility for the employer to oblige the employee to work remotely if there are no other opportunities to perform work duties. Although this may appear to be an unjustified interference with worker's privacy, at first sight, such interference can have a legitimate basis if it is provided for by law or if it is intended to ensure the health and safety of other workers.

\section{Sources}

\section{Bibliography}

1. Kaugtöö kokkulepe [Agreement on telework]. 25.05.2017. Available: https://www.eakl.ee/ kokkulepped/kaugtoo-kokkulepe [last viewed 26.02.2021].

2. Eesti infoühiskonna arengukava kuni 2020 [Development plan for Estonian information society until 2020]. Available: https://www.mkm.ee/sites/default/files/eesti_infouhiskonna_arengukava. pdf [last viewed 27.02.2021].

3. Guide on Article 8 of the European Convention on Human Rights. Available: https://www.echr. coe.int/documents/guide_art_8_eng.pdf [last viewed 26.02.2021].

4. Haddon, L., Brynin, M. The Character of Telework and the Characteristics of Teleworkers. 2005. Available: http://eprints.lse.ac.uk/67001/1/Haddon_character_of_telework.pdf [last viewed 26.02.2021].

5. Lõhmus, U. Lisandusi inimõiguste konventsiooniga võetud kohustuste peatamisele [In addition to suspended obligations arising from the Human Rights Convention]. Available: https://www.err. ee/1070879/uno-lohmus-lisandusi-inimoiguste-konventsiooniga-voetud-kohustuste-peatamisele [last viewed 26.02.2021].

6. Töötamisega seotud regulatsioone tuleb muuta paindlikumaks [Regulations concerning employment must be more flexible]. Available: https://www.koda.ee/et/uudised/tootamisega-seotud-regulatsioonetuleb-muuta-paindlikumaks [last viewed 27.02.2021]. 
7. Reinsalu: hädaolukorras võidakse piirata inimõiguste konventsioonis tagatud õigusi [Reinsalu: In case of emergency human rights can be restricted]. Available: https:/www.delfi.ee/news/ paevauudised/eesti/reinsalu-hadaolukorras-voidakse-piirata-inimoiguste-konventsioonistagatud-oigusi?id=89384059 [last viewed 26.02.2021].

8. Telework in the EU before and after the COVID-19: Where we were, where do we head to. Available: https://ec.europa.eu/jrc/sites/jrcsh/files/jrc120945_policy_brief_-_covid_and_telework_final. pdf [last viewed 28.02.2021].

9. Kaugtöötaja töötervishoid ja - ohutus [Teleworker - occupational health and safety]. Available: https://www.tooelu.ee/UserFiles/Sisulehtede-failid/Teemad/Paindlikud\%20t\%C3\%B6\%C3\% B6v\%C3\%B5imalused/Kaugtootaja\%20tootervishoiu\%20ja\%20-ohutuse\%20juhis.pdf [last viewed 26.02.2021].

\section{Normative Acts}

1. European Human Rights Convention. Available: https://www.echr.coe.int/Documents/ Convention_ENG.pdf [last viewed 27.02.2021].

2. Directive 2003/88/EC of the European Parliament and Council of 4 November 2003 concerning certain aspects of the organisation of working time. Available: https://eur-lex.europa.eu/legalcontent/EN/TXT/PDF/?uri=CELEX:32003L0088\&from=ET [last viewed 26.02.2021].

3. The Constitution of the Republic of Estonia. Available: https://www.riigiteataja.ee/en/ eli/530122020003/consolide [last viewed 26.02.2021].

4. Civil Service Act. Available: https://www.riigiteataja.ee/en/eli/525032019003/consolide [last viewed 26.02.2021].

5. Employment Contracts Act. Available: https://www.riigiteataja.ee/en/eli/529122020003/ consolide [last viewed 27.02.2021].

6. Occupational Health and Safety Act. Available: https://www.riigiteataja.ee/en/eli/522022021001/ consolide [last viewed 26.02.2021].

7. Regulation (EU) 2016/679 of the European Parliament and of the Council of 27 April 2016 on the protection of natural persons with regard to the processing of personal data and on the free movement of such data, and repealing Directive 95/46/EC (General Data Protection Regulation). Available: https://eur-lex.europa.eu/eli/reg/2016/679/oj [last viewed 13.09.2021].

\section{Case Law}

1. Judgment of the Court (Grand Chamber) of 14 May 2019. Federación de Servicios de Comisiones Obreras (CCOO) v. Deutsche Bank SAE. Case C-55/18, 14 May 2019. Available: https://eur-lex. europa.eu/legal-content/EN/TXT/?uri=CELEX\%3A62018CJ0055 [last viewed 26.02.2021]. 